\title{
The Effects of Management Practices on Grassland Birds
}

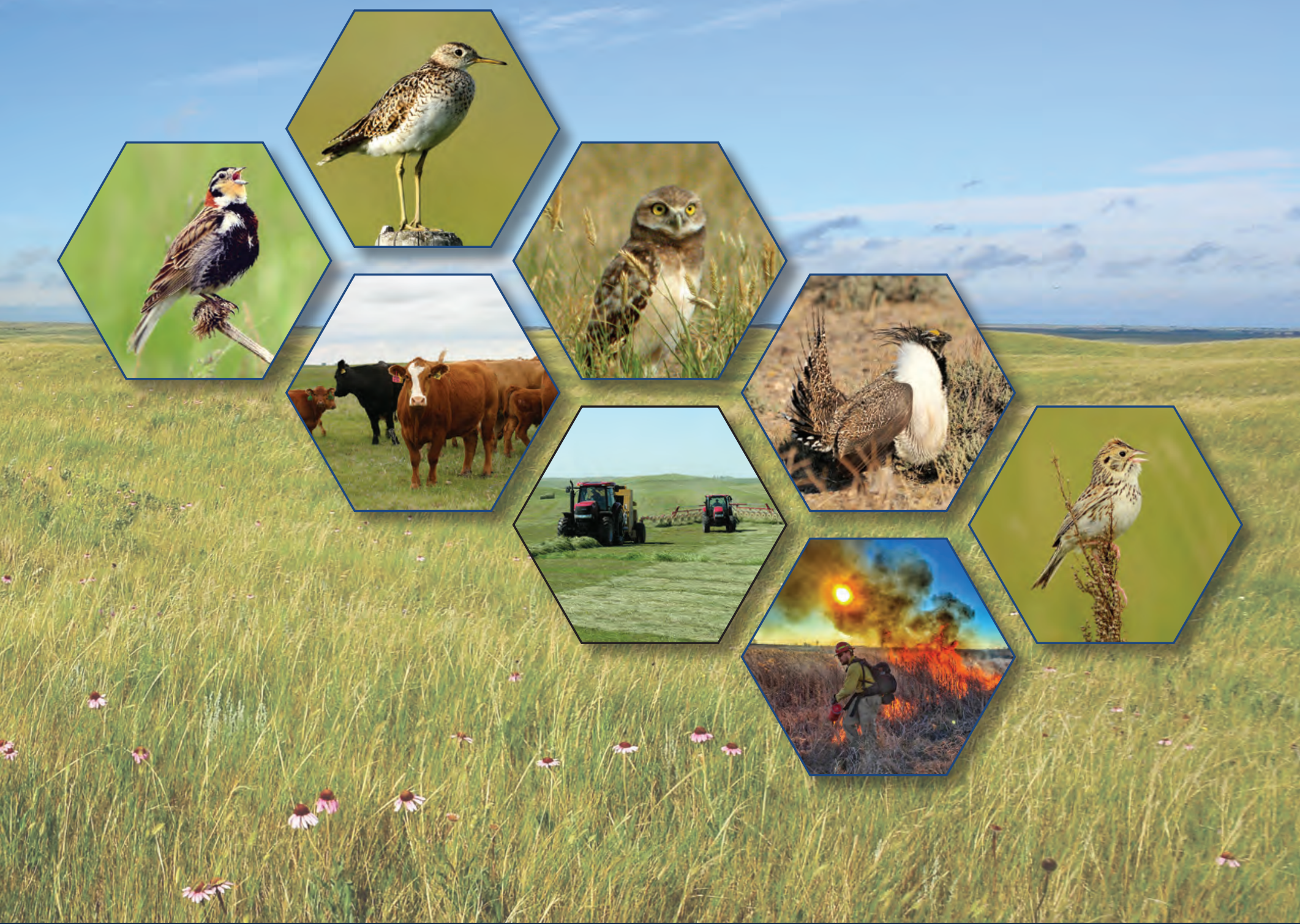

Professional Paper 1842 Version 1.1, March 2022

U.S. Department of the Interior U.S. Geological Survey 


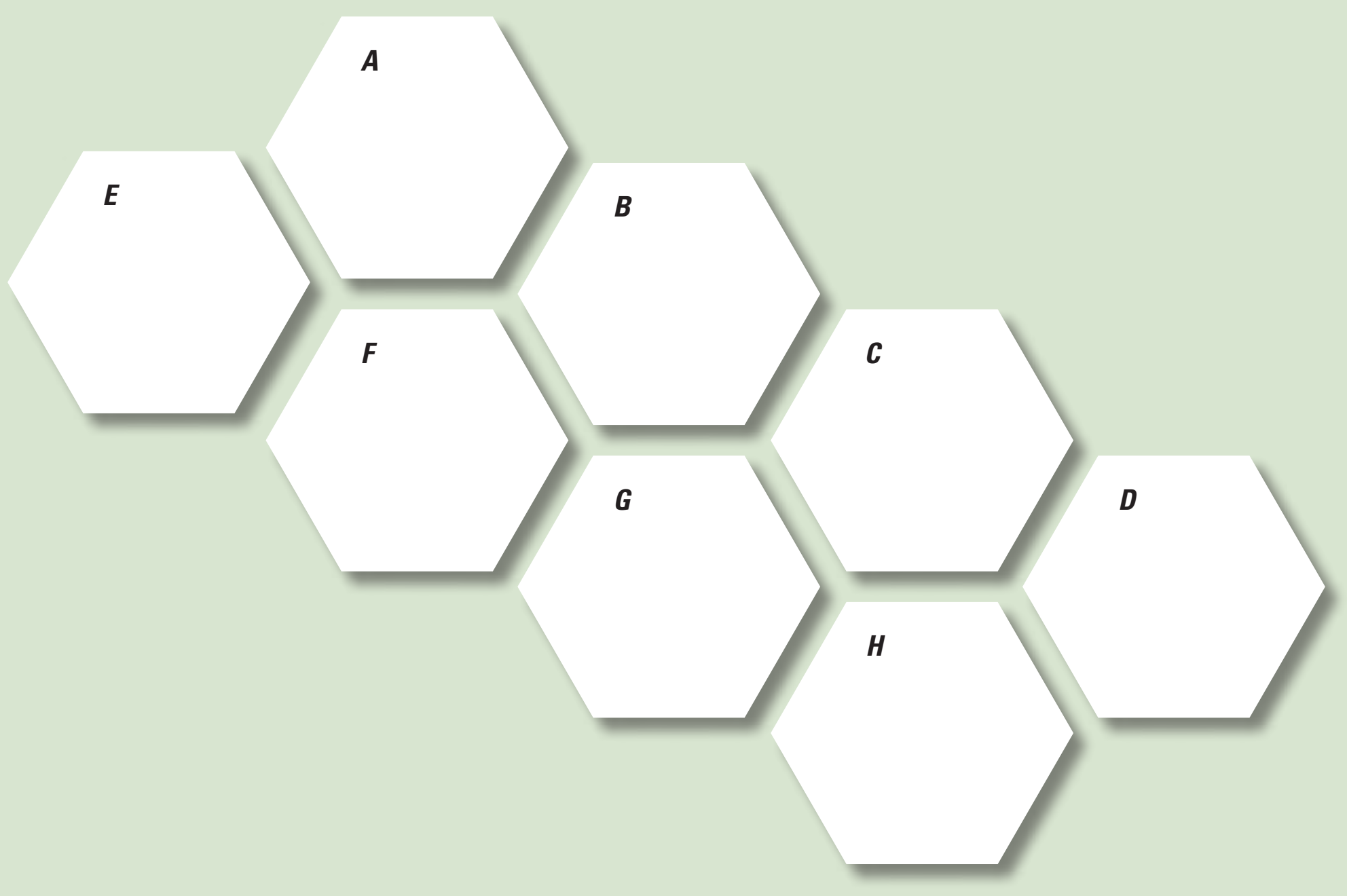

Cover. A, Upland Sandpiper, by Rick Bohn, used with permission. B, Burrowing Owl, by David O. Lambeth, used with permission. C, Greater Sage-Grouse, by Tom Koerner, U.S. Fish and Wildlife Service. D, Baird's Sparrow, by Rick Bohn, used with permission. E, Chestnut-collared Longspur, by Rick Bohn, used with permission. $F$, Cattle grazing in McPherson County, South Dakota, by Lawrence D. Igl, U.S. Geological Survey. G, Hay baling and raking, by Rick Bohn, used with permission. H, Prescribed burn, by Jennifer Jewett, U.S. Fish and Wildlife Service.

Background photograph: Northern mixed-grass prairie in North Dakota, by Rick Bohn, used with permission. 


\title{
The Effects of Management Practices on Grassland Birds
}

\author{
Edited by Douglas H. Johnson, ${ }^{1}$ Lawrence D. Igl, ${ }^{1}$ Jill A. Shaffer, ${ }^{1}$ and John P. DeLong ${ }^{1,2}$
}

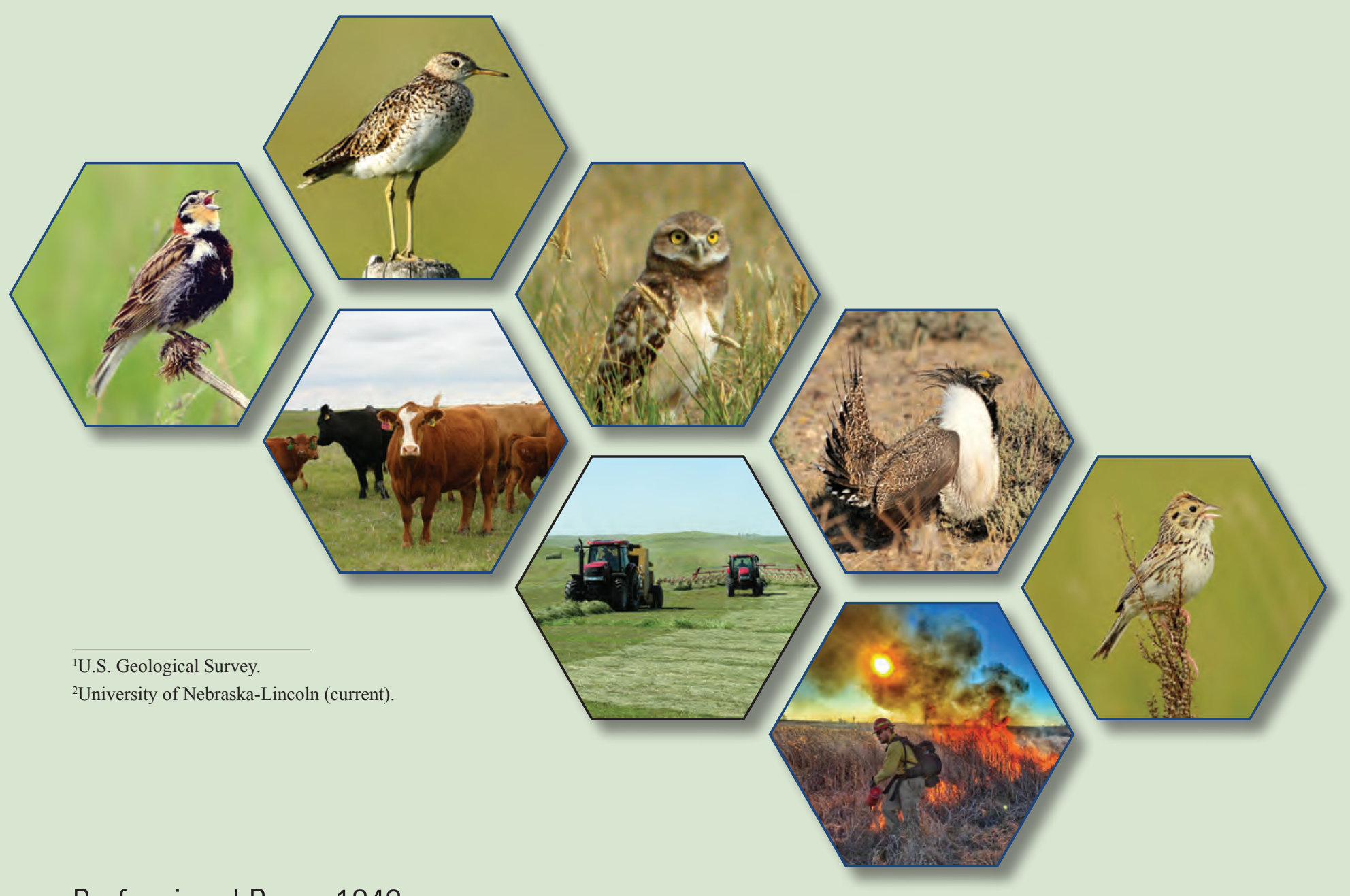

Professional Paper 1842

Version 1.1, March 2022

U.S. Department of the Interior

U.S. Geological Survey 


\section{U.S. Department of the Interior DAVID BERNHARDT, Secretary}

\section{U.S. Geological Survey James F. Reilly II, Director}

\section{U.S. Geological Survey, Reston, Virginia: 2019}

First release: 2019

Revised: March 2022 (ver 1.1)

For more information on the USGS - the Federal source for science about the Earth, its natural and living resources, natural hazards, and the environment—visit https://www.usgs.gov or call 1-888-ASK-USGS.

For an overview of USGS information products, including maps, imagery, and publications, visit https://store.usgs.gov.

Any use of trade, firm, or product names is for descriptive purposes only and does not imply endorsement by the U.S. Government.

Although this information product, for the most part, is in the public domain, it also may contain copyrighted materials as noted in the text. Permission to reproduce copyrighted items must be secured from the copyright owner.

Suggested citation:

Johnson, D.H., Igl, L.D., Shaffer, J.A., and DeLong, J.P., eds., 2019, The effects of management practices on grassland birds (ver. 1.1, March 2022): U.S. Geological Survey Professional Paper 1842, https://doi.org/10.3133/pp1842. 


\section{Foreword}

One of the admittedly few advantages of living and working in North Dakota is that there is an abundance of dark winter days when an ornithologist can best spend his or her time in a library, researching the very prairie-adapted birds that, when spring finally arrives, will return to delight the eye and ear, and by then will fully occupy the rapidly increasing daylight hours. This, at least, is how I would like to imagine that this wonderful series of species accounts on the ecology of grassland birds were written. My own childhood and teenage years were spent in North Dakota, where the anticipation of witnessing the spring return of such magical grassland birds as Marbled Godwits and Upland Sandpipers made the interminable winter months barely tolerable. These and other localized grassland birds, such as Greater Prairie-Chickens and Burrowing Owls, indelibly affected my adolescence, and secured my allegiance to the grassland biotas of the Great Plains for the next five decades of my life.

Several summers ago, I returned to North Dakota to attend the funeral of my mother, who had been raised on a farm that her grandparents homesteaded amid the tallgrass prairies of the Sheyenne River Valley. After the service, I drove out to these very grasslands, now part of the Sheyenne National Grassland, and watched Upland Sandpipers perform display flights above their territories, which seemed an altogether fitting counterpoint to end that sad day. Prairie roses were in full bloom, and even from a distance I could recognize far more of the other native grassland grasses and forbs than I could when I was a child. I gave silent thanks that a few such plant and animal treasures still may be found at the fringes of a high-tech agricultural society. However, these grasslands are restricted to a relatively small Pleistocene-age delta of the Sheyenne River that was too sandy to cultivate and are nearly the last remnants of native tallgrass prairie in North Dakota.

At that time, in the early 2000s, I had only recently finished work on my book "Prairie Birds: Fragile Splendor in the Great Plains," for which I had filled several notebooks with reference materials on grassland birds. One of these notebooks contains a draft set of "The Effects of Management Practices on Grasslands Birds," which I had eagerly acquired from the U.S. Geological Survey's Northern Prairie Wildlife Research Center as rapidly as the individual accounts became available. The series was of tremendous value to me in my literature surveys while writing my book on grassland birds, because the American Ornithologists' Union's monograph series "The Birds of North America" (now managed by the Cornell Lab of Ornithology) was then still incomplete and lacked accounts for several of the typical grassland species. Additionally, "The Effects of Management Practices on Grassland Birds" series offered a generally stronger ecological emphasis than did "The Birds of North America" accounts, especially as to each species' breeding biology and habitat requirements. Finally, the bibliographic references for each species often were nearly comparable in number to those in "The Birds of North America" series, and occasionally (as in the Burrowing Owl account) were even more numerous, greatly facilitating my ease of literature scans. 
Now, in these days of ever-declining natural habitats, and especially of diminishing populations of nearly all of the grassland-dependent birds, the value of "The Effects of Management Practices on Grassland Birds" accounts in trying to preserve viable populations of prairie birds is especially great. Many of the prairie sites that existed near my current home in Lincoln, Nebraska, have disappeared before my eyes in the past 40 years - the songs of Western Meadowlarks that I could hear across the road from our house when we first moved in have been replaced by the noises of traffic, gas-powered lawnmowers, and snow blowers. Knowledge of minimum areas needed for territories and home ranges by breeding grassland birds, the capacity for assessing and ameliorating dangers of brood parasitism by Brown-headed Cowbirds, and assessments of tolerance levels for noise and human disturbance are, for example, now of much greater significance than they were a half century ago. To learn what is currently known about these and similar subjects affecting grassland bird populations, one can do no better than to start with this sourcebook.

\section{Paul A. Johnsgard \\ Foundation Regents Professor Emeritus School of Biological Sciences University of Nebraska-Lincoln}




\section{Preface}

Since the mid-1960s, populations of grassland birds have been declining more precipitously than any other group of birds in North America. These long-term declines highlight the need to better understand the habitat requirements of grassland birds and how management practices affect individual species and their habitats. Although resource managers have long recognized that every management approach contains inherent advantages and disadvantages, depending on the species in question, they are often faced with making critical management decisions armed with little or no information. The need for information on management and its effects on grassland birds was identified by the U.S. Prairie Pothole Joint Venture, a part of the North American Waterfowl Management Plan, in support of its objective to stabilize or increase populations of declining grassland-and wetland-associated wildlife species in the Prairie Pothole Region. In 1996, scientists from the U.S. Geological Survey's Northern Prairie Wildlife Research Center began a long-term, collaborative effort to review and synthesize literature on the effects of management practices on grassland bird species. Major funding for this effort was provided by the Prairie Pothole Joint Venture, U.S. Fish and Wildlife Service, and the U.S. Geological Survey; additional funding was provided by the U.S. Forest Service, The Nature Conservancy, and the Plains and Potholes Landscape Conservation Cooperative. This compendium on "The Effects of Management Practices on Grassland Birds" is a culmination of that work. More than 6,000 published and unpublished publications have been consulted and several thousand publications have been incorporated and synthesized in species accounts for 40 North American grassland bird species. The 40 species represent a taxonomically diverse group that includes grouse, shorebirds, owls, diurnal raptors, and many songbirds. The focus of this effort is on management of breeding habitat, with an emphasis on the Great Plains. The accounts provide land managers with a summary of information on the effects of specific management practices on grassland birds and help to identify the most critical research gaps in our understanding of grassland bird ecology, habitat needs, and responses to management practices.

Grasslands are biological communities that are dominated by grasses and forbs (nongrass herbaceous plants) and that have sparse coverage of trees and shrubs. Grasslands are referred to by many names, including prairies, steppes, savannas, rangeland, and parkland. Unifying characteristics of grasslands include a climate punctuated by periodic droughts, disturbances (such as fire and grazing that limit woody vegetation), and level-to-rolling terrain. Grasslands may be in small patches or cover large areas, and despite a fairly uniform appearance, there may be considerable variation in vegetative structure and composition within individual grasslands. A grassland bird is a species that relies on grassland habitats to support some portion of its life cycle, including breeding, migration, or wintering needs. 
This compendium is organized into three primary sections: an introduction, species accounts, and a concluding chapter. The introduction provides an overview of grasslands, the processes under which grasslands formed, the influence of anthropogenic changes to grasslands, the effects of those changes on grassland bird populations, and the management tools available to land managers. The bulk of this compendium is the individual species accounts, covering 40 species of North American grassland birds arranged in taxonomic order. Each species account includes information on species range, suitable breeding habitat, area requirements and landscape associations, breeding-season phenology, species' response to management, and management recommendations. Information on rates of brood parasitism by the Brown-headed Cowbird (Molothrus ater) in grassland bird nests is summarized in a chapter at the end of this report. The final chapter includes concluding remarks concerning habitat requirements and management effects on grassland birds.

Each species account begins with a brief "Capsule Statement" section, which provides the fundamental components or keys to management for the species. The capsule statement also provides numerical ranges for measured vegetation parameters important to breeding birds. A section on "Breeding Range" outlines the current breeding distribution of the species in North America, including areas that could not be mapped using North American Breeding Bird Survey data. A "Range Map" is provided to indicate the relative densities and breeding range of the species in North America, based on Breeding Bird Survey data (2008-12), other published sources, or information provided by experts for a particular bird species. Although birds are frequently observed outside the breeding range indicated, the maps are intended to show areas where managers might concentrate their attention. It may be ineffective to manage habitat at a site for a species that rarely occurs in that area.

The "Suitable Habitat" section describes the breeding habitat and occasionally microhabitat characteristics of the species, especially those habitats that occur in the Great Plains. Details on habitat requirements often provide clues to how a species will respond to a particular management practice. A special section on "Prey Habitat" is included for those predatory avian species that have more specific prey requirements. A table on bird-vegetation characteristics at the end of each account (except for some raptor species) complements the section on suitable habitat and lists the specific breeding habitat characteristics for the species reported by individual studies. The table also includes information on study location (State or Province), habitat type, and management practices or treatment.

The section on "Area Requirements and Landscape Associations" provides details on territory and home-range sizes; minimum area requirements; and the effects of patch size, edge, and other landscape and habitat features on grassland bird abundance and productivity. It may be futile to manage a small block of suitable habitat for a species that has minimum area requirements that are much larger than the area being managed. 
The Brown-headed Cowbird is an obligate brood parasite of nests of many grassland bird species. The section on "Brood Parasitism by Cowbirds and Other Species" summarizes rates of parasitism by cowbirds and other species; host responses to parasitism; and factors that affect parasitism, such as nest concealment, proximity to edge habitats, and host densities.

The effects of management on grassland birds depend, in part, on a species' breeding-season phenology, site fidelity, and nesting biology. The section on "Breeding-Season Phenology and Site Fidelity" includes details on spring arrival and fall departure for migratory populations in the Great Plains, peak breeding periods, the tendency to renest after nest failure or success, and the propensity to return to their birthplace (natal-site fidelity) or a previous breeding site (breedingsite fidelity).

The "Species' Response to Management" section summarizes the current knowledge and major findings in the literature on the effects of different management practices, especially burning, mowing, and grazing, on the species. This section also contains information on how anthropogenic activities, such as urbanization and energy development, affect individual species. The section on "Management Recommendations from the Literature" complements the previous section and summarizes specific recommendations for habitat management provided in the literature. If management recommendations differ in different portions of the species' breeding range, recommendations are given separately by region.

In an effort to standardize terminology among studies and among species accounts, various descriptors were used to denote the type of management treatment or habitat. Idle used as a modifier (for example, idle tallgrass) denotes undisturbed or unmanaged (for example, not burned, mowed, or grazed) areas. Idle by itself denotes unmanaged areas in which the plant species were not mentioned. Tame denotes introduced plant species that are not native to North American prairies. Native denotes plant species that are native to North American prairies and may occur in unbroken prairies, planted grasslands, and prairie restorations. Hayland refers to any habitat that was mowed, regardless of whether or not the resulting cut vegetation was removed. Burned includes habitats that were burned intentionally or accidentally or those burned by natural forces (for example, lightning). In situations where there are two or more descriptors, the first descriptor modifies the subsequent descriptors. For example, idle tame hayland is habitat that is usually mowed annually but happened to be undisturbed during the year of the study.

Finally, we would like to acknowledge the accomplishments and efforts of the many researchers and managers who have contributed to the growing body of literature on the effects of management practices on grassland birds. This compendium reflects their commitment, progress, and insight, and their efforts will provide a solid foundation for future advances in understanding the effects of management on grassland birds. 


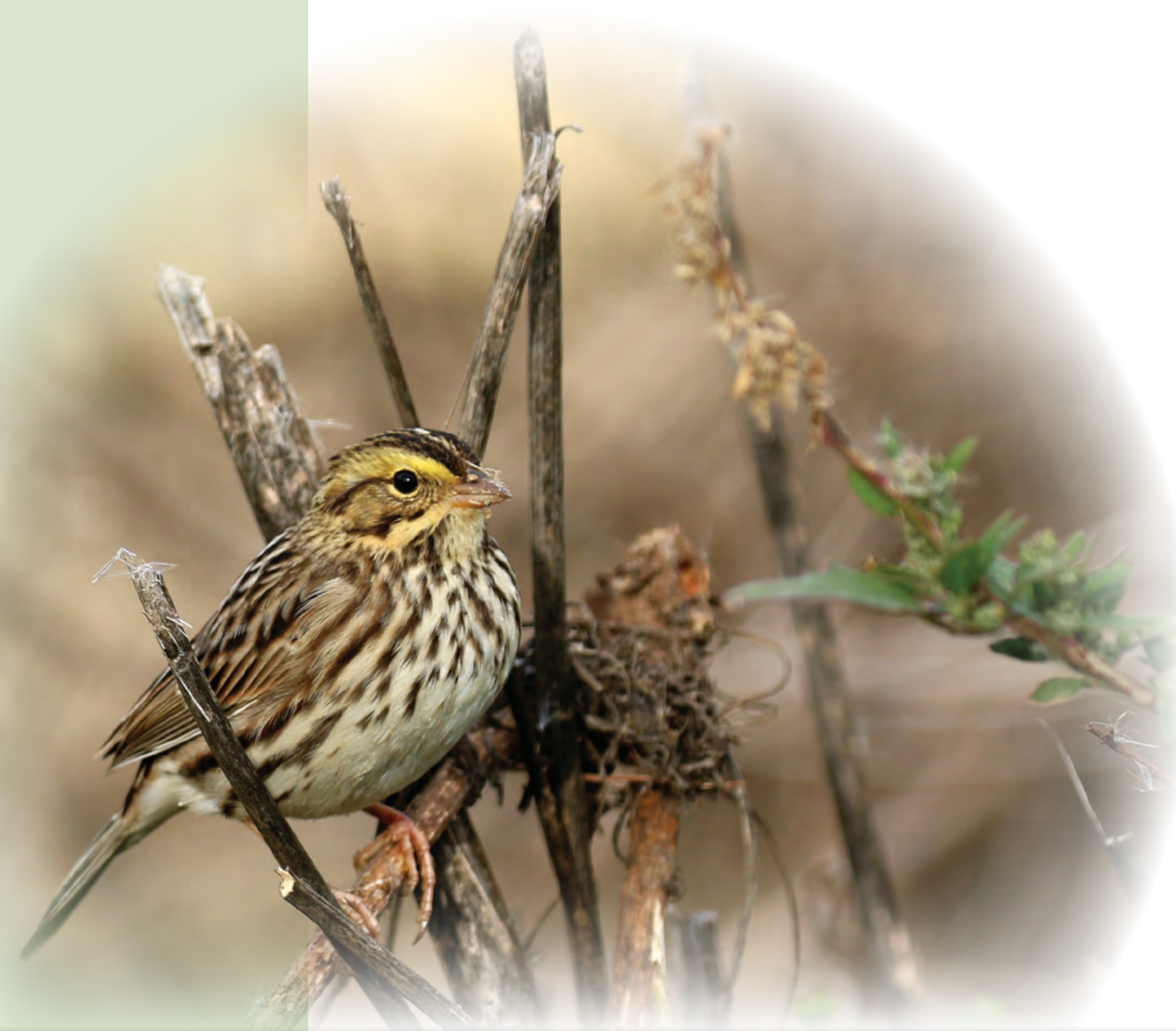




\title{
The Effects of Management Practices on Grassland Birds
}

\author{
Edited by Douglas H. Johnson, Lawrence D. Igl, Jill A. Shaffer, and \\ John P. DeLong
}

\section{Chapters}

A. The Effects of Management Practices on Grassland Birds-An Introduction to North American Grasslands and the Practices Used to Manage Grasslands and Grassland Birds

By Jill A. Shaffer and John P. DeLong

B. The Effects of Management Practices on Grassland Birds - Greater Sage-Grouse (Centrocercus urophasianus)

By Mary M. Rowland

C. The Effects of Management Practices on Grassland Birds - Greater Prairie-Chicken (Tympanuchus cupido)

By W. Daniel Svedarsky, John E. Toepfer, Ronald L. Westemeier, Robert J. Robel, Lawrence D. Igl, and Jill A. Shaffer

D. The Effects of Management Practices on Grassland Birds-Lesser Prairie-Chicken (Tympanuchus pallidicinctus)

By Brent E. Jamison, Lawrence D. Igl, Jill A. Shaffer, Douglas H. Johnson, Christopher M. Goldade, and Betty R. Euliss

E. The Effects of Management Practices on Grassland Birds-Mountain Plover (Charadrius montanus)

By Jill A. Shaffer, Lawrence D. Igl, Douglas H. Johnson, Marriah L. Sondreal, Christopher M. Goldade, Melvin P. Nenneman, Travis L. Wooten, and Betty R. Euliss

F. The Effects of Management Practices on Grassland Birds-Upland Sandpiper (Bartramia longicauda)

By Jill A. Shaffer, Lawrence D. Igl, Douglas H. Johnson, Meghan F. Dinkins,

Christopher M. Goldade, Barry D. Parkin, and Betty R. Euliss

G. The Effects of Management Practices on Grassland Birds—-Long-billed Curlew (Numenius americanus)

By Jill A. Shaffer, Lawrence D. Igl, Douglas H. Johnson, Marriah L. Sondreal,

Christopher M. Goldade, Paul A. Rabie, and Betty R. Euliss 
H. The Effects of Management Practices on Grassland Birds-Marbled Godwit (Limosa fedoa)

By Jill A. Shaffer, Lawrence D. Igl, Douglas H. Johnson, Marriah L. Sondreal, Christopher M. Goldade, Melvin P. Nenneman, and Betty R. Euliss

I. The Effects of Management Practices on Grassland Birds-Willet

(Tringa semipalmata inornata)

By Jill A. Shaffer, Lawrence D. Igl, Douglas H. Johnson, Marriah L. Sondreal, Christopher M. Goldade, Barry D. Parkin, Jason P. Thiele, and Betty R. Euliss

J. The Effects of Management Practices on Grassland Birds-Wilson's Phalarope (Phalaropus tricolor)

By Jill A. Shaffer, Lawrence D. Igl, Douglas H. Johnson, Christopher M. Goldade, Amy L. Zimmerman, and Betty R. Euliss

K. The Effects of Management Practices on Grassland Birds-American Bittern (Botaurus lentiginosus)

By Jill A. Shaffer, Lawrence D. Igl, Douglas H. Johnson, Marriah L. Sondreal, Christopher M. Goldade, Amy L. Zimmerman, Travis L. Wooten, and Betty R. Euliss

L. The Effects of Management Practices on Grassland Birds-Northern Harrier (Circus hudsonius)

By Jill A. Shaffer, Lawrence D. Igl, Douglas H. Johnson, Marriah L. Sondreal, Christopher M. Goldade, Melvin P. Nenneman, Jason P. Thiele, and Betty R. Euliss

M. The Effects of Management Practices on Grassland Birds-Swainson's Hawk (Buteo swainsoni)

By Jill A. Shaffer, Lawrence D. Igl, Douglas H. Johnson, Meghan F. Dinkins, Christopher M. Goldade, Travis L. Wooten, and Betty R. Euliss

N. The Effects of Management Practices on Grassland Birds-Ferruginous Hawk (Buteo regalis)

By Jill A. Shaffer, Lawrence D. Igl, Douglas H. Johnson, Marriah L. Sondreal, Christopher M. Goldade, Amy L. Zimmerman, Jason P. Thiele, and Betty R. Euliss

O. The Effects of Management Practices on Grassland Birds-Golden Eagle (Aquila chrysaetos)

By John P. DeLong

P. The Effects of Management Practices on Grassland Birds-Burrowing Owl (Athene cunicularia hypugaea)

By Jill A. Shaffer, Lawrence D. Igl, Douglas H. Johnson, Marriah L. Sondreal, Christopher M. Goldade, Paul A. Rabie, Jason P. Thiele, and Betty R. Euliss

Q. The Effects of Management Practices on Grassland Birds-Short-eared Owl (Asio flammeus)

By Jill A. Shaffer, Lawrence D. Igl, Douglas H. Johnson, Marriah L. Sondreal, Christopher M. Goldade, Melvin P. Nenneman, and Betty R. Euliss 
R. The Effects of Management Practices on Grassland Birds-Merlin (Falco columbarius)

By Paul M. Konrad, Jill A. Shaffer, and Lawrence D. Igl

S. The Effects of Management Practices on Grassland Birds_-Prairie Falcon (Falco mexicanus)

By John P. DeLong and Karen Steenhof

T. The Effects of Management Practices on Grassland Birds-Loggerhead Shrike (Lanius ludovicianus)

By Jill A. Shaffer, Lawrence D. Igl, Douglas H. Johnson, Marriah L. Sondreal,

Christopher M. Goldade, Melvin P. Nenneman, Amy L. Zimmerman, Jason P. Thiele, and Betty R. Euliss

U. The Effects of Management Practices on Grassland Birds-Horned Lark

(Eremophila alpestris)

By Meghan F. Dinkins, Lawrence D. Igl, Jill A. Shaffer, Douglas H. Johnson,

Amy L. Zimmerman, Barry D. Parkin, Christopher M. Goldade, and Betty R. Euliss

V. The Effects of Management Practices on Grassland Birds-Sedge Wren

(Cistothorus stellaris)

By Jill A. Shaffer, Lawrence D. Igl, Douglas H. Johnson, Marriah L. Sondreal,

Christopher M. Goldade, Barry D. Parkin, Travis L. Wooten, and Betty R. Euliss

W. The Effects of Management Practices on Grassland Birds - Sprague's Pipit

(Anthus spragueii)

By Jill A. Shaffer, Lawrence D. Igl, Douglas H. Johnson, Marriah L. Sondreal,

Christopher M. Goldade, Melvin P. Nenneman, Travis L. Wooten, Jason P. Thiele, and Betty R. Euliss

X. The Effects of Management Practices on Grassland Birds - Chestnut-collared Longspur (Calcarius ornatus)

By Jill A. Shaffer, Lawrence D. Igl, Douglas H. Johnson, Marriah L. Sondreal, Christopher M. Goldade, Melvin P. Nenneman, Travis L. Wooten, and Betty R. Euliss

Y. The Effects of Management Practices on Grassland Birds-Thick-billed Longspur (Rhynchophanes mccownii)

By Jill A. Shaffer, Lawrence D. Igl, Douglas H. Johnson, Marriah L. Sondreal, Christopher M. Goldade, Paul A. Rabie, Travis L. Wooten, and Betty R. Euliss

Z. The Effects of Management Practices on Grassland Birds - Clay-colored Sparrow (Spizella pallida)

By Jill A. Shaffer, Lawrence D. Igl, Douglas H. Johnson, Marriah L. Sondreal, Christopher M. Goldade, Melvin P. Nenneman, and Betty R. Euliss 


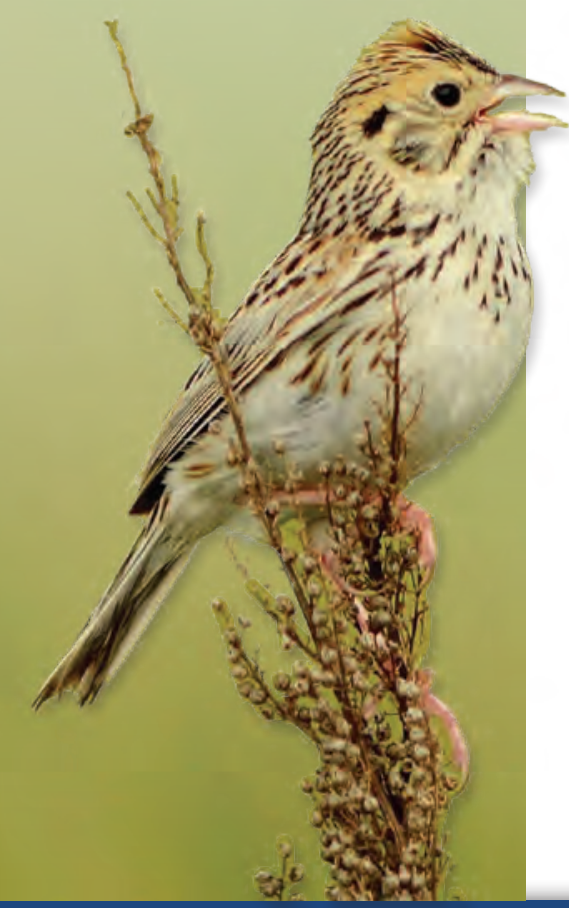

AA. The Effects of Management Practices on Grassland Birds-Brewer's Sparrow (Spizella breweri breweri)

By Brett L. Walker, Lawrence D. Igl, and Jill A. Shaffer

BB. The Effects of Management Practices on Grassland Birds-Field Sparrow (Spizella pusilla)

By Jill A. Shaffer, Lawrence D. Igl, Douglas H. Johnson, Marriah L. Sondreal, Christopher M. Goldade, Barry D. Parkin, and Betty R. Euliss

CC. The Effects of Management Practices on Grassland Birds-Vesper Sparrow (Pooecetes gramineus)

By Jill A. Shaffer, Lawrence D. Igl, Douglas H. Johnson, Meghan F. Dinkins, Christopher M. Goldade, and Betty R. Euliss

DD. The Effects of Management Practices on Grassland Birds-Lark Sparrow (Chondestes grammacus)

By Jill A. Shaffer, Lawrence D. Igl, Douglas H. Johnson, Marriah L. Sondreal, Christopher M. Goldade, Barry D. Parkin, and Betty R. Euliss

EE. The Effects of Management Practices on Grassland Birds_-Lark Bunting (Calamospiza melanocorys)

By Jill A. Shaffer, Lawrence D. Igl, Douglas H. Johnson, Marriah L. Sondreal, Christopher M. Goldade, Amy L. Zimmerman, and Betty R. Euliss

FF. The Effects of Management Practices on Grassland Birds-Savannah Sparrow (Passerculus sandwichensis)

By David A. Swanson, Jill A. Shaffer, and Lawrence D. Igl

GG. The Effects of Management Practices on Grassland Birds-Grasshopper Sparrow (Ammodramus savannarum)

By Jill A. Shaffer, Lawrence D. Igl, Douglas H. Johnson, Marriah L. Sondreal, Christopher M. Goldade, Melvin P. Nenneman, Travis L. Wooten, and Betty R. Euliss

HH. The Effects of Management Practices on Grassland Birds-Baird's Sparrow (Centronyx bairdii)

By Jill A. Shaffer, Lawrence D. Igl, Douglas H. Johnson, Marriah L. Sondreal, Christopher M. Goldade, Melvin P. Nenneman, and Betty R. Euliss

II. The Effects of Management Practices on Grassland Birds-Henslow's Sparrow (Centronyx henslowii)

By James R. Herkert

JJ. The Effects of Management Practices on Grassland Birds-LeConte's Sparrow (Ammospiza leconteii)

By Jill A. Shaffer, Lawrence D. Igl, Douglas H. Johnson, Marriah L. Sondreal, Christopher M. Goldade, Amy L. Zimmerman, and Betty R. Euliss 
KK. The Effects of Management Practices on Grassland Birds-Nelson's Sparrow (Ammospiza nelsoni nelsoni)

By Jill A. Shaffer, Lawrence D. Igl, Douglas H. Johnson, Marriah L. Sondreal, Christopher M. Goldade, Paul A. Rabie, and Betty R. Euliss

LL. The Effects of Management Practices on Grassland Birds-Bobolink (Dolichonyx oryzivorus)

By Jill A. Shaffer, Lawrence D. Igl, Douglas H. Johnson, Marriah L. Sondreal, Christopher M. Goldade, Amy L. Zimmerman, Travis L. Wooten, and Betty R. Euliss

MM. The Effects of Management Practices on Grassland Birds-Eastern Meadowlark (Sturnella magna)

By Scott D. Hull, Jill A. Shaffer, and Lawrence D. Igl

NN. The Effects of Management Practices on Grassland Birds-Western Meadowlark (Sturnella neglecta)

By Jill A. Shaffer, Lawrence D. Igl, Douglas H. Johnson, Marriah L. Sondreal, Christopher M. Goldade, Amy L. Zimmerman, Travis L. Wooten, and Betty R. Euliss

OO. The Effects of Management Practices on Grassland Birds-Dickcissel (Spiza americana) By Jill A. Shaffer, Lawrence D. Igl, Douglas H. Johnson, Marriah L. Sondreal, Christopher M. Goldade, Amy L. Zimmerman, and Betty R. Euliss

PP. The Effects of Management Practices on Grassland Birds-Rates of Brown-headed Cowbird (Molothrus ater) Parasitism in Nests of North American Grassland Birds By Jill A. Shaffer, Lawrence D. Igl, and Douglas H. Johnson

QQ. The Effects of Management Practices on Grassland Birds - Concluding Remarks on the Infusion of Information from the Literature to Improve and Support Management Decisions that Affect Grassland Birds

By Lawrence D. Igl 
My own childhood and teenage years were spent in North Dakota, where the anticipation of witnessing the spring return of such magical grassland birds as Marbled Godwits and Upland Sandpipers made the interminable winter months barely tolerable. These and other localized grassland birds, such as Greater Prairie-Chickens and Burrowing Owls, indelibly affected my adolescence, and secured my allegiance to the grassland biotas of the Great Plains...

\section{From Foreword by Paul A. Johnsgard}


For more information about this publication, contact: Director, USGS Northern Prairie Wildlife Research Center 8711 37th Street Southeast Jamestown, ND 58401

701-253-5500

For additional information, visit: https://www.usgs.gov/centers/npwrc Publishing support provided by the Rolla Publishing Service Center 
